\title{
Radiographic Analysis of Root Canal Fillings: Influence of Two Sealers on the Perception of Voids
}

\author{
Augusto BODANEZI ${ }^{1}$ \\ Etiene de Andrade MUNHOZ ${ }^{2}$ \\ Norberti BERNARDINELI ${ }^{1}$ \\ Ana Lúcia Álvares CAPELOZZA² \\ Ivaldo Gomes de MORAES ${ }^{1}$ \\ Clovis Monteiro BRAMANTE ${ }^{1}$ \\ ${ }^{1}$ Department of Dentistry, Endodontics and Dental Materials, \\ Bauru Dental School, University of São Paulo, Bauru, SP, Brazil \\ ${ }^{2}$ Department of Stomatology, Radiology and Oral Surgery, Bauru Dental School, \\ University of São Paulo, Bauru, SP, Brazil
}

\begin{abstract}
The aim of this ex vivo was to investigate if two radiopaque root canal sealers with different formulations would influence the radiographic perception of root canal fillings. The root canals of 48 extracted maxillary canines were prepared and randomly assigned to 3 groups of 16 specimens each. In each group, the root canals were filled by lateral condensation of gutta-percha and one of the tested sealers: Endométhasone, Sealer 26, or a non-radiopaque sealer. A through-and-through void was simulated in half of the specimens from each group $(n=8)$. The buccolingual radiographic images obtained were randomly interpreted for voids existence by a radiologist and an endodontist. The differences in sensitivity and specificity between groups and examiners were compared using, respectively, Fisher's Exact and McNemar tests at 5\% significance level. Both radiopaque sealers caused a significant decrease in sensitivity at the coronal part of fillings. The use of Endométhasone increased specificity values for both coronal and apical portions of the root canal fillings. In conclusion, the tested sealers influenced the radiographic perceptions of laterally condensed root canal fillings in a different way.
\end{abstract}

Key Words: diagnosis, radiography, radiopacity, root canal filling, sealer.

\section{INTRODUCTION}

The examination of endodontically treated teeth for restorative purposes requires a detailed radiographic analysis of root canal fillings because it seems to be the most accessible non-invasive method to obtain objective information that helps deciding on the need for revising the treatment. In the moment that the radiography is assessed, the recognition of voids caused by procedural inability is extremely important for the reason that these empty spaces have potential to promote leakage of bacteria and toxins to the periapex, thus compromising success of treatment (1).

Radiopacity is an essential attribute of root canal sealers and gutta-percha, since this property allows for clear distinction of root fillings and also for estimation of their extent and apparent condensation into root canals
(2-5). Routinely, radiopacity of commercially available sealers is ranked on in vitro tests, but the significance of this information to the radiographic appearance of root fillings is never mentioned (5-7). The image of an obturation on radiography consists of a two-dimensional, usually buccolingual, projection of filling materials confined in the root canal and superimposed with bone, dentin, and soft tissue. During lateral condensation, a sealer is applied to fill spaces between gutta-percha cones, which the bulk of fillings fails to reach and, for this reason, it may have an impact on the radiopacity of root fillings (4).

It is well established that intracanal distribution of sealers is determined by their particular physicochemical properties $(8,9)$ and the filling technique adopted (10). Sealer 26 and Endométhasone are commercially available root canal sealers that, in spite of remarkable dif-

Correspondence: Dr. Augusto Bodanezi, Departamento de Dentística, Endodontia e Materiais Dentários, Faculdade de Odontologia de Bauru, USP, Alameda Dr. Octávio Pinheiro Brizolla, 9-75, CP. 73, 17012-901 Bauru, SP, Brasil. Tel:+55-14-3235-8344. Fax: +55-14-3235-8345. e-mail: aboda@usp.br 
ferences in formulations and physicochemical properties (11-13), have shown similar in vitro radiopacity when investigated alone or associated with gutta-percha (6). Given this configuration, the present study investigated if two root canal sealers with different formulations would influence the radiographic perception of defective (sensitivity) or adequate (specificity) root canal fillings performed with lateral condensation.

\section{MATERIAL AND METHODS}

\section{Tooth Preparation}

For this study, 48 maxillary permanent maxillary canines with single straight or slightly curved root canals $(25 \pm 2 \mathrm{~mm})$ were selected and stored in $0.5 \%$ saline solution after approval of the research project by the University of São Paulo's Research Ethics Committee (Protocol \#153/2005). After standard access, root canal lengths were assessed by placing a size $15 \mathrm{~K}$-file (Dentsply-Maillefer, Ballaigues, Switzerland) inside the canal, until the tip has passed through the apical foramen. The instrument was withdrawn $1 \mathrm{~mm}$ to record the working length. All canals were instrumented using a push-pull filing technique up to a size $55 \mathrm{~K}$-file and, after every instrument withdrawal from the root canal, a full irrigation with $1 \%$ sodium hypochlorite was performed (Virex; Johnson Ltd., Jacarepaguá, RJ, Brazil). Apical foramen enlargement was obtained with a size $25 \mathrm{~K}$-file. After a 3 min final irrigation with 17\% EDTA (Biodinâmica, Ibiporã, PR, Brazil), the root canals were rinsed with $0.5 \%$ saline and dried thoroughly with paper points.

The specimens were randomly assigned to 3 groups ( $\mathrm{n}=16)$. In each group, the root canals were filled by lateral condensation of gutta-percha and one of the tested sealers: Endométhasone (Septodont, Saint-Maurdes-Fossés, Cedex, France), Sealer 26 (Dentsply Ind e Com., Petrópolis, RJ, Brazil), and a non-radiopaque sealer (NRS) which was used in the control group and formulated with epoxy resin, resin hardener and polyurethane polyol. The commercially available sealers were handled and mixed according to manufacturer's recommendations (Table 1), whereas the non-radiopaque sealer compound was homogenized for $15 \mathrm{~s}$.
Before being filled with lateral condensation, a radiolucent nylon monofilament string $(0.25 \mathrm{~mm}$ in diameter and $20 \mathrm{~cm}$ in length) (Grilon Fishing Line; Mazzaferro Ltd., São Bernardo do Campo, SP, Brazil) was inserted into the root canal of half specimens from each group $(n=8)$. Both ends of the string were tied in alignment to a device so that moving the tooth distally would stabilize the stretched fishing line in contact with the mesial wall of the root canal through the whole filling procedures, conducted by one operator.

The sealers were taken to the root canals by coating with respective master gutta-percha cone. A size 30 master cone was exclusively used for root canals provided with nylon thread, while a size 55 cone was inserted into the remaining root canals. The master cone was laterally condensed with A and B finger spreaders (Dentsply-Maillefer), and 7 to 9 accessory cones (Tanari, Manacapuru, AM, Brazil) were added to the filling mass (Fig. 1). After obturation, coronally extruded excess sealer and gutta-percha were cleaned.

\section{Radiographic Procedure}

Radiographs of each canine were obtained in the buccolingual direction using the paralleling technique. The periapical E film (Insight; Kodak Co., Rochester, NY, USA) and each filled tooth were maintained in a constant position by inserting each root in the same canine socket of a phantom build from a dry human maxilla, which was fixed in a rigid position, in front of $\mathrm{X}$-ray tube, with a specifically designed acrylic device.

All radiographic exposures were completed with a dental X-ray unit (X 70; Dabi Atlante, Ribeirão Preto, $\mathrm{SP}$, Brazil) at $70 \mathrm{kVp}$ and $8 \mathrm{~mA}$. The exposure time was

Table 1. Composition and powder/liquid or paste/liquid ratio of the tested materials.

\begin{tabular}{|c|c|c|}
\hline Sealer & Composition & Ratio \\
\hline Endomèthasone & $\begin{array}{l}\text { Zinc oxide, dexamethasone, } \\
\text { hydrocortisone acetate, thymol iodine, } \\
\text { paraformaldehyde, lead oxide, barium } \\
\text { sulphate, magnesium estearate, } \\
\text { bismuth subnitrate, eugenol }\end{array}$ & $\begin{array}{c}3.6: 1 \\
\text { (powder/liquid) }\end{array}$ \\
\hline Sealer 26 & $\begin{array}{l}\text { Bismuth oxide, calcium hydroxide, } \\
\text { hexamethylenetetramine, titanium } \\
\text { dioxide, epoxy bisphenol }\end{array}$ & $\begin{array}{c}2.2: 1 \\
\text { (powder/liquid) }\end{array}$ \\
\hline $\begin{array}{l}\text { Non-radiopaque } \\
\text { sealer }\end{array}$ & $\begin{array}{l}\text { Epoxy resin, resin hardener, } \\
\text { polyurethane polyol }\end{array}$ & $\begin{array}{c}2: 1 \\
\text { (paste/liquid) }\end{array}$ \\
\hline
\end{tabular}


$0.5 \mathrm{~s}$, the focus-object distance was $40 \mathrm{~cm}$, and the object to receptor distance was $2 \mathrm{~cm}$.

The exposed films were immersed in the developer solution for $3 \mathrm{~min}$ at $21^{\circ} \mathrm{C}$ and then rinsed with water for $10 \mathrm{~s}$ before being submerged in the fixer solution for $8 \mathrm{~min}$. The developed films were subsequently washed with running water for $10 \mathrm{~min}$ and allowed to dry in a dust free atmosphere.

\section{Image Evaluation}

All radiographic evaluations were performed with the aid of an ethyl-vinyl-acetate mask positioned over a fluorescent cold light-box (Medalight LP-400; Hong Kong, China) in the same light-controlled room. Prior to image assessment, an endodontist and a radiologist received written instructions and were then calibrated with a pair of radiographs. The 48 radiographs were numbered, mounted in random order, and individually interpreted. The resulting images were analyzed for the presence or absence of voids in the coronal, medium, and/or apical third of the root canal filling (Fig. 2). The observers had no knowledge of the extent and distribution of voids and were asked to ignore the distance of fillings to the apex or radiolucent areas in contact with the root. Analyses of images were recorded in a proper form and the viewing time was unlimited. A second evaluation was executed 4 weeks after the first assessment.

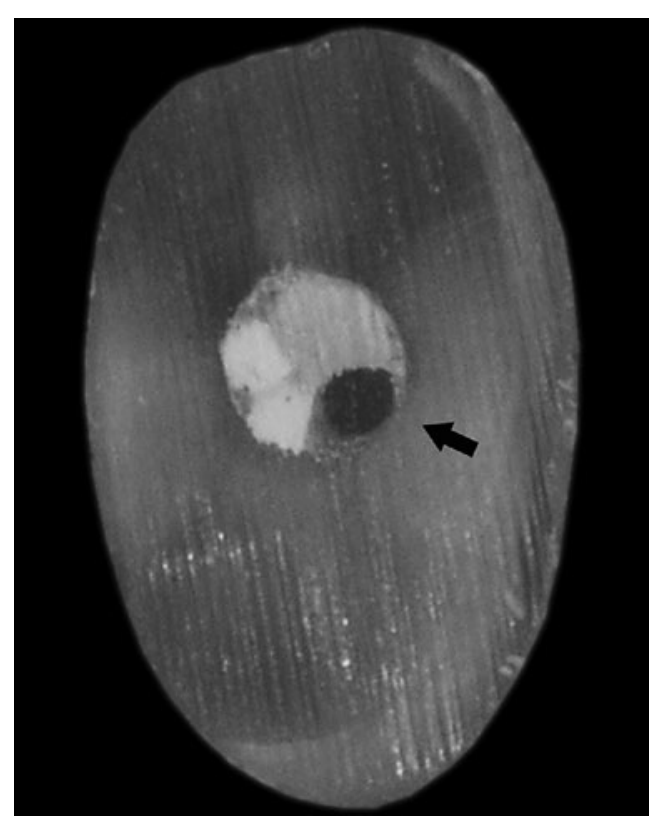

Figure 1. Apical cross-section of the root canal filling showing the nylon thread used to simulate the void (arrow).

\section{Statistical Analysis}

The mean number of correct, false positive, incorrect and false negative results obtained from both sequential assessment stages was used as the basis for sensitivity and specificity calculations for each group. The differences in sensitivity and specificity values between groups and examiners were compared using categorical Exact Fisher's and McNemar tests, respectively, which were both adjusted to the $95 \%$ confidence interval. The intra-observer agreement was determined by Cohen's Kappa statistic method. Statistical evaluation for all tests was performed with SPSS database software program (SPSS v. 11.0 for Windows, Chicago, IL, USA).

\section{RESULTS}

\section{Sensitivity}

In the assessment by the endodontist, the experimental groups had statistically lower sensitivity values than the control group only for the coronal third of root canal fillings (Table 2). However, the differences in sensitivity between groups were not statistically significant in any part of fillings when they were evaluated by the radiologist. The coronal part of Endométhasone and Sealer 26 fillings exhibited statistically lower sensitiv-

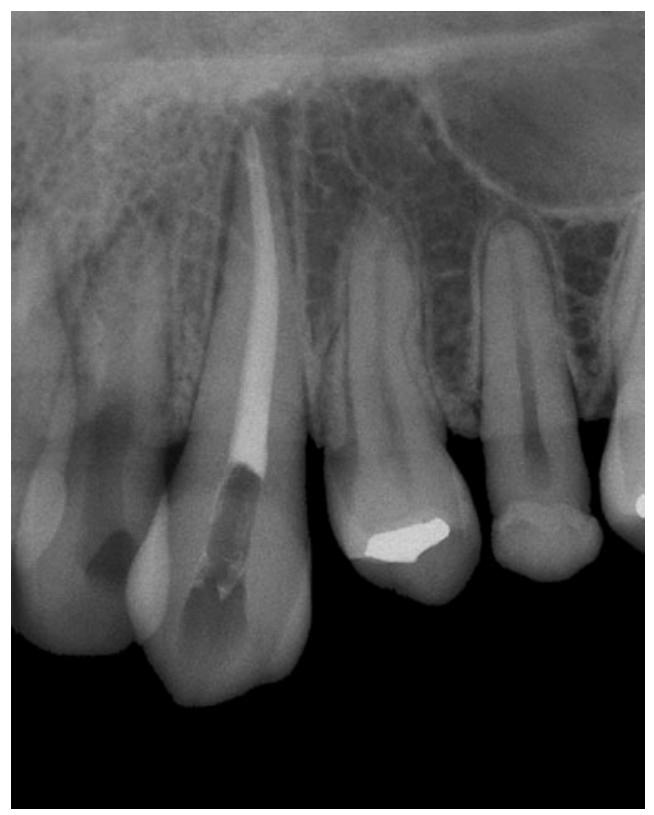

Figure 2. Representative radiographic image of the root canal fillings assessed by the examiners. Note the presence of the simulated void in the apical third. 
ity values than the apical part for both examiners. In the control group, this difference was only observed in the assessment by the radiologist. There were statistically higher sensitivity values for the endodontist's evaluation of control (cervical part) when compared to the radiologist's examination (Table 2). The sensitivity values obtained in the middle of root fillings were not statistically different from the coronal and apical parts of fillings for the two examiners.

\section{Specificity}

The coronal and apical parts of Endométhasone root canal fillings exhibited statistically higher values of specificity than the control group for the radiologist's and endodontist's assessment (Table 3 ). The differences in specificity between the coronal and apical thirds of experimental and control groups were not statistically significant, even when compared to the specificity values obtained in the middle part of the root canal fillings. There were no statistically differences between the specificity values obtained from the different examiners.
The intra-observer Kappa values were 0.81 for the radiologist and 0.87 for the endodontist.

\section{DISCUSSION}

The analysis of periapical radiography is one of the most common diagnostic tests used in dentistry and, in this study, all efforts were conducted to reproduce as close as possible the radiographic image of maxillary canine root canal fillings normally obtained and assessed in clinical practice.

In previous investigations, an empty space of $0.25 \mathrm{~mm}$ in the obturation was considered the threshold to decide whether a root canal filling appeared well or was imperfectly condensed on radiography $(3,14)$. Based on this representation, we adopted in this work a nylon string of equivalent size to simulate an empty space inside root canals. This maneuver permitted for some standardization of thickness, position, and even apical extension of the void through the entire obturation, which is a characteristic almost impossible to control in clinical studies $(1,15)$. Despite the efforts to keep the

Table 2. Mean values and ranges of sensitivity in each third of the fillings assessed by the examiners.

\begin{tabular}{lcccc}
\hline Sealers & Examiner & Coronal & Middle & Apical \\
\hline \multirow{2}{*}{ Endométhasone } & Endodontist & $0.13(0.13-0.13)^{\mathrm{a} \S}$ & $0.63(0.63-0.63)$ & $1.00(1.00-1.00)^{\mathrm{a}}$ \\
& Radiologist & $0.06(0.13-0.00)^{\mathrm{b}}$ & $0.38(0.38-0.38)$ & $0.81(0.88-0.75)^{\mathrm{b}}$ \\
\multirow{2}{*}{ Sealer 26 } & Endodontist & $0.50(0.50-0.50)^{\mathrm{c}^{*}}$ & $0.57(0.63-0.50)$ & $0.81(0.88-0.75)^{\mathrm{c}}$ \\
& Radiologist & $0.12(0.25-0.00)^{\mathrm{d}}$ & $0.50(0.63-0.38)$ & $0.81(0.88-0.75)^{\mathrm{d}}$ \\
NRS & Endodontist & $0.82(1.00-0.63)^{\S^{*} \mathrm{~F}}$ & $0.69(0.75-0.63)$ & $0.94(1.00-0.88)$ \\
& Radiologist & $0.19(0.38-0.00)^{\mathrm{eF}}$ & $0.44(0.63-0.25)$ & $0.75(0.88-0.63)^{\mathrm{e}}$ \\
\hline
\end{tabular}

Same lowercase letters indicate statistically significant difference among the filling regions. Same symbols indicate statistically significant difference between groups. Same uppercase letters indicate statistically significant difference between examiners.

Table 3. Mean values and ranges of specificity in each third of the fillings assessed by the examiners.

\begin{tabular}{lcccc}
\hline Sealers & Specialty & Coronal & Middle & Apical \\
\hline \multirow{2}{*}{ Endométhasone } & Endodontist & $1.00(1.00-1.00)^{\mathrm{a}}$ & $1.00(1.00-1.00)$ & $1.00(1.00-1.00)^{\mathrm{c}}$ \\
& Radiologist & $1.00(1.00-1.00)^{\mathrm{b}}$ & $1.00(1.00-1.00)$ & $0.94(0.88-1.00)^{\mathrm{d}}$ \\
\multirow{2}{*}{ Sealer 26 } & Endodontist & $0.69(0.63-0.75)$ & $0.87(0.74-1.00)$ & $0.81(0.63-1.00)$ \\
& Radiologist & $0.81(0.63-1.00)$ & $0.94(0.87-1.00)$ & $0.81(0.63-1.00)$ \\
NRS & Endodontist & $0.50(0.38-0.62)^{\mathrm{a}}$ & $0.75(0.63-0.87)$ & $0.62(0.38-0.87)^{\mathrm{c}}$ \\
& Radiologist & $0.62(0.25-1.00)^{\mathrm{b}}$ & $0.94(0.87-1.00)$ & $0.62(0.38-0.87)^{\mathrm{d}}$ \\
\hline
\end{tabular}

Same lowercase letters indicate statistically significant differences among the filling regions. 
string attached to the mesial root canal wall, a central dislodgement due to subtle distal curvature of root apex must have occurred.

False positive assertions were surely originated from detection of inherent minor voids resulting from unfilled spreader tracks, insufficient sealer distribution or operational variability generated during lateral condensation $(3,14,16)$, and this probably had some influence on the results. In order to estimate and neutralize this bias, natural root canal fillings were performed with a radiolucent sealer (control group).

According to the results presented, both sealers caused an equivalent reduction in sensitivity, especially at the coronal part of fillings. This phenomenon may have resulted from the thicker mass of gutta-percha added to sealer accumulation at this point, which is a natural characteristic of lateral condensation (9). The oval-shaped configuration of canine root canals $(3,10)$ and the buccolingual direction of radiographic exposure may have also contributed for the radiographic superimposition that probably hid the simulated void. Conversely, in similar studies the root level did not affected void detection in canine fillings $(17,18)$, but major methodological differences such as filling techniques, the use of filling materials separately and simulated void accomplishment with wires should be considered.

In the apical region of fillings, the highest sensitivity levels were independent of the sealer used, indicating that screening for defects at this area offers the most significant opportunity to correctly detect voids in root canals manually prepared and filled with lateral condensation. Probably the lower content of sealer and the large thickness of the simulated void both contributed to the absence of statistical difference between the experimental groups. The identification of voids in the apical part of fillings by means of radiography is important because, though distant from coronal potential microleakage, the apex may harbor bacteria that can grow when they receive nutrients from periapical region or lateral canals, thus compromising treatment (1).

When the coronal and apical regions of root fillings were evaluated, the root canal fillings performed with Endométhasone presented a statistically lower number of false positive results (higher specificity) than Sealer 26. In an attempt to explain the reasons for this phenomenon, technical or operational deficiencies associated with lateral condensation procedures $(3,14,16)$ and the difficulties in standardizing the volume of sealer reaching the apical region (16) should be considered as possible causes for an uneven distribution of undesirable filling defects between groups. Similarly, the differences in sealers' formulations and mixing characteristics could also influence on physicochemical properties that were able to configure the intracanal distribution of sealers (8-10). Almeida et al. (13) reported that Endométhasone has a significant lower flow (higher viscosity) when compared to Sealer 26 . This property is directly related to the amount of radiopaque sealer's accumulated between gutta-percha cones in the moment of filling procedures (19) and, for this reason, may have had an influence on the final radiopacity of root canal fillings (20). The supposed thicker layers of Endométhasone probably superimposed a great number of inherent filling voids than Sealer 26 did and, concomitantly, increased the general radiographic density of root fillings to a level which was recognized as a sign of good quality by the examiners $(3,14)$. However, it should be clear that no physicochemical properties of sealers were evaluated in this study.

The dissonance detected between examiners, in the assessment of control group (defective fillings), resulted in no conclusive evidence regarding whether the radiopacity provided by gutta-percha alone would conceal the simulated void in the coronal and thickest portion of fillings. Likewise, the endodontist considered a higher number of voids in root canal fillings performed with Endométhasone. Since diagnostic decision is influenced by personal experience and previous knowledge of the subject analyzed $(4,17,18)$, a suspicious attitude of the endodontist towards root canal treatments performed by unknown professionals could possibly explain the higher proportion of voids detected by this professional compared to the radiologist. In addition, it should be clear that only one specialist of each area was compared, thus these results are neither scientifically nor statistically powerful to support generalizations on specialties' decision-making during radiographic judgment of fillings.

The present study was designed to investigate if radiographic perception of root canal filling homogeneity depended only on sealers' radiopacity. Considering that this hypothesis was rejected, it seems difficult to establish a correlation between radiopacity levels, ranked by the current in vitro protocols, and the resulting appearance of laterally condensed fillings perceived in periapical radiographs, as suggested by Beyer-Olsen and Ørstavik (2). Likewise, the bulk of laterally condensed fillings is radiopaque gutta-percha, thus it was not possible to 
dissociate the sealers' radiopacity effect from that generated by the entire filling on the radiographic image. Therefore, it should be assumed that sealers are capable of influencing only the overall radiopacity of the filling, as already stated by Baksi et al. (4).

Although digital intraoral techniques seemed to perform better than the analogue intraoral images for small void detection in canine fillings (18), the influence of sealers' formulation on radiographic perception of root canal fillings presented in this study advises that diagnostic decision should never rely solely upon radiographic image. The act of gathering information from a detailed history and clinical examination as well as the awareness that root canal shape and filling techniques exert some influence on the diagnostic performance of periapical radiographs should be carefully considered in order to reduce the chances of misjudgment in the prognosis of difficult cases.

Based on the results of this study it seems that the tested sealers influenced the radiographic perception of laterally condensed root canal fillings in different ways.

\section{RESUMO}

O propósito deste estudo ex vivo foi investigar se dois cimentos obturadores de fórmulas diferentes influenciariam a percepção radiográfica de obturações de canais radiculares. Os canais radiculares de 48 caninos superiores extraídos foram preparados e divididos em 3 grupos. Em cada grupo os canais foram preenchidos através da condensação lateral da gutapercha e de um dos cimentos testados (Endométhasone, Sealer 26 e cimento não-radiopaco), e um defeito de ponta a ponta foi simulado em metade dos espécimes de cada grupo $(n=8)$. As imagens radiográficas vestíbulo-linguais obtidas foram aleatoriamente interpretadas quanto à existência de defeitos por um radiologista e um endodontista. As diferenças em sensibilidade e especificidade entre os grupos e examinadores foram comparadas respectivamente usando-se os testes Exato de Fisher e McNemar ajustados ao nível de significância de 5\%. Ambos os cimentos radiopacos ocasionaram uma redução significativa da sensibilidade na parte cervical das obturações. O uso do Endométhasone aumentou os valores de especificidade para as porções cervical e apical das obturações dos canais radiculares. Concluiu-se que os cimentos testados influenciaram de maneira distinta a percepção radiográfica de obturações endodônticas executadas com condensação lateral.

\section{REFERENCES}

1. Sundqvist G, Figdor D, Persson S, Sjögren U. Microbiologic analysis of teeth with failed endodontic treatment and the outcome of conservative re-treatment. Oral Surg Oral Med Oral Pathol Oral
Radiol Endod 1998;85:86-93.

2. Beyer-Olsen EM, Ørstavik D. Radiopacity of root canal sealers. Oral Surg Oral Med Oral Pathol 1981;51:320-328.

3. van der Sluis LWM, Wu M-K, Wesselink PR. An evaluation of the quality of root fillings in mandibular incisors and maxillary and mandibular canines using different methodologies. J Dent 2005;33:683-688.

4. Baksi BG, Eyüboğlu TF, Şen BH, Erdilek N. The effect of three different sealers on the radiopacity of root fillings in simulated canals. Oral Surg Oral Med Oral Pathol Oral Radiol Endod 2007; 103:138-141.

5. Carvalho-Junior JR, Correr-Sobrinho L, Correr AB, Sinhoreti MAC, Consani S, Souza-Neto MD. Radiopacity of root filling materials using digital radiography. Int End J 2007;40:514-520.

6. Ferreira FBA, Silva e Souza PAR, Bevilaqua MV, Tavano O. Digital radiographic assesment of endodontic cements radiopacity $\mathrm{J}$ Appl Oral Sci (Formerly Rev Fac Odontol Bauru) 1999;7:55-60.

7. Tanomaru-Filho M, Jorge EG, Tanomaru JMG, Gonçalves M. Evaluation of the radiopacity of calcium hydroxide- and glassionomer-based root canal sealers. Int End J 2008;41:50-53.

8. McMichen FR, Pearson G, Rahbaran S, Gulabivala K. A comparative study of selected physical properties of five root-canal sealers. Int End J 2003;36:629-635.

9. Facer SR, Walton RE. Intracanal distribution patterns of sealers after lateral condensation. J Endod 2003;29:832-834.

10. Wu M-K, Özok AR, Wesselink PR. Sealer distribution in root canals obturated by three techniques. Int End J 2000;33:340-345.

11. Souza-Neto MD, Marchesan MA, Pécora JD, Junior AB, SilvaSouza YT, Saquy PC. Effect of Er:YAG laser on adhesion of root canal sealers. J Endod 2002;28:185-187.

12. Gomes BP, Pedroso JÁ, Jacinto RC, Vianna ME, Ferraz CC, Zaia $\mathrm{AA}$, et al.. In vitro evaluation of the antimicrobial activity of five root canal sealers. Braz Dent J 2004;15:30-35.

13. Almeida JF, Gomes BP, Ferraz CC, Souza-Filho FJ, Zaia AA. Filling of artificial lateral canals and microleakage and flow of five endodontic sealers. Int Endod J 2007;40:692-699.

14. Kersten HW, Wesselink PR, Thoden van Velzen SK. The diagnostic reliability of the buccal radiograph after root canal filling. Int End J 1987;20:20-24.

15. Eckerbom M, Flygare L, Magnusson T. A 20-year follow-up study of endodontic variables and apical status in a Swedish population. Int End J 2007;40:940-948.

16. Souza EM, Wu M-K, van der Sluis LW, Leonardo RT, BonettiFilho I, Wesselink PR. Effect of filling technique and root canal area on the percentage of gutta-percha in laterally compacted root fillings. Int End J 2009;42:719-726.

17. Kositbowornchai S, Hanwachirapong D, Somsopon R, Pirmsinthavee S, Sooksuntisakoonchai N. Ex vivo comparison of digital images with conventional radiographs for detection of simulated voids in root canal filling material. Int End J 2006;39:287-292.

18. Huybrechts B, Bud M, Bergmans L, Lambrechts P, Jacobs R. Void detection in root fillings using intraoral analogue, intraoral digital and cone beam CT images. Int End J 2009;42:675-685.

19. Weisman MI. A study of the flow rate of ten root canal sealers. Oral Surg Oral Med Oral Pathol 1970;29:255-261.

20. Orfali S, Lilley JD, Molokhia A. The radiopacity of some endodontic sealer cements [Abstract 368]. J Dent Res 1987;66:876.

Accepted March 16, 2010 